\title{
Freedom of Expression, Social Media Censorship, and Property Rights
}

\author{
Pavel Slutskiy \\ Chulalongkorn University (Thailand)
}

\begin{abstract}
Sustainable Development Goal 16 stresses the importance of access to information. It is clearly emphasised in target 16.10 — "to ensure public access to information and protect fundamental freedoms, in accordance with national legislation and international agreements". With social media becoming the default communication platforms, the questions of the extent to which their content moderating models are conducive to the implementation of public access to information and fundamental freedoms are becoming increasingly important. Facebook,

looks at the controversy surrounding these policies from the property rights perspective -focusing on the role which property rights play in securing the freedom of expression. By recognising the owners' right to control the legitimately owned property, I conclude that social media are not engaged in "censorship" —-they merely exercise property rights. There is a difference between a private platform refusing to carry someone's ideas on their property and a government prohibiting from speaking on a legitimately owned property.
\end{abstract} Instagram, Tumblr as well as Twitter and other social media platforms have been recently criticised for censorship of user-generated content. This article

Keywords: SDG 16.10, freedom of expression, censorship, social media, property rights.

I $\mathrm{n}$ this article I will endeavour to analyse current controversies regarding free speech, censorship and social media content moderating policies. The relevance of this topic hardly needs any justification or explanation - freedom of expression has long been considered a key element for securing fundamental human rights. Without having the freedom of seeking, receiving, and imparting information or ideas, regardless of the medium used, individual rights can not be secured.

Sustainable Development Goal 16, particularly the targets on fundamental freedoms, specifically stresses the importance of access to information and the 
rule of law. It is clearly spelled out in the target of 16.10 — "to ensure public access to information and protect fundamental freedoms, in accordance with national legislation and international agreements".

Conceptualization of information freedom is increasingly associated with the freedom of access to information. In other words, in discussing the issue of information freedom, it is important to recognise that its practical outworking needs to take into account how rights to information operate and the nature of the communicative infrastructure in place to facilitate access among other factors. With social media the default communicative infrastructure element, the questions of the extent to which their content models are conducive to the implementation of public access to information and fundamental freedoms is becoming increasingly important.

At the same time, Facebook, Instagram, Tumblr as well as Twitter and other social media platforms have been recently criticised (and perhaps rightly so) for their censorship of user-generated content (deleting posts of banning users altogether). These policies have been criticised for both inconsistency and inefficiency of implementation, as well as for general incompatibility of post-by-post moderation with free speech principles.

The amount critical attention to the question of social media responsibility increased during and after Donald Trump's presidential campaign, when Russian agents attempted to attack Democratic candidates. Following the charges of Russian meddling in the presidential elections in 2016, including the Mueller investigation and the publication of the Report on the Investigation into Russian Interference in the 2016 Presidential Election, the questions of influencing elections via cyber voter interference and the general accountability of social media platforms became the focus of research on political communication and social media (e.g. Casero-Ripollés, 2018, Hansen and Lim, 2019; Mazúr and Patakyová, 2019).

I intend to demonstrate that this critique is fundamentally flawed logically, and social media platforms do have the right to moderate users' content, and that such moderation does not represent a threat to achieving the target of 16.10 SDG; on the contrary, correct understanding of freedom of expression would suggest that any interference with the rights of social media platforms to determine their own content policies would constitute a much more dangerous move in the direction of violating the principle of free speech. To support this proposition I will primarily rely on the idea that the very concept of free speech is inseparable from property rights. Because property rights are the source of the freedom of expression, the opposite would also be true - any interference with property rights would detrimental to people's otherwise abstract liberty to speak freely.

\section{THE CONCEPT OF RIGHTS REVISITED}

To trace the origins of this idea I need to begin by revising the concept of rights and the relationship between freedom and power, as well as the concept of negative and positive rights. I will begin with the ideas that were clearly articulated by Murray Rothbard, who clarified the distinction between freedom and power: 
Any man has freedom of will, freedom to choose the course of his life and his actions.

Some critics have charged that this freedom is illusory because man is bound by natural laws. This, however, is a misrepresentation-one of the many examples of the persistent modem confusion between freedom and power. Man is free to adopt values and to choose his actions; but this does not at all mean that he may violate natural laws with impunity - that he may, for example, leap oceans at a single bound. In short, when we say that "man is not 'free' to leap the ocean", we are really discussing not his lack of freedom but his lack of power to cross the ocean, given the laws of his nature and of the nature of the world ... man, not being omnipotent as well as not being omniscient, always finds his power limited for doing all the things that he would like to do. In short, his power is necessarily limited by natural laws, but not his freedom of will. To put the case another way it is patently absurd to define the "freedom" of an entity as its power to perform an act impossible for its nature! (Rothbard, 1998: 34).

This of course, echoes Locke's concept of liberty:

[T] he Idea of Liberty, is the Idea of a Power in any Agent to do or forbear any particular Action, according to the determination or thought of the mind, whereby either of them is preferred to the other (Locke, 1690/1975, II: xxi.8).

Understanding the difference between freedom and power is important — the lack of power is distinct from the limitations of the laws of nature. If we go back to Rothbard's example of man's "freedom to leap the ocean" then of course a man may not have the power to do it, but he is free to purchase a ticket on a plane that will cross the ocean. However, having the freedom to purchase the ticket does not mean the right to possess the ticket —all that freedom means is the lack of external restrictions to perform the action in accordance to human nature and intentions.

This is the principal difference between positive and negative rights. Negative rights determine people's obligations to refrain from performing certain actions towards others, which means that respecting these rights does not require performing any actions. As Isaiah Berlin formulated it in his famous lecture,

liberty in the negative sense involves an answer to the question: "What is the area within which the subject - a person or group of persons - is or should be left to do or be what he is able to do or be, without interference by other persons" (Berlin, 1958: 2).

These rights protect individuals from unwanted, unsolicited interference and restrictions which limit their freedom, these rights are fundamental and absolute.

Positive rights, on the contrary, assert that to respect them other people need to provide an individual with some goods, perform some actions. All social rights are in essence positive rights - like the right to education, healthcare or housing. These rights can not be realised without some coercion - violation of negative rights of others.

A negative right means that initiating force in illegitimate, whereas positive rights man that aggression can be legitimately used to force someone to do some- 
thing or delegate that some entity (for example, the government) initiate force to secure these rights. In the example used above everyone's positive right to crossing the ocean would mean that the universe owes to everyone a plane ticket, and a situation when someone wants to have a ticket but does not have one is unjust. The universe or other individuals are thus obligated to give this person a ticket. This is an illustration of the principle according to which positive rights are obligations imposed on other people (since the ticket is not free, it is implied that others would have to pay for it). One can have a negative right to cross the ocean and buy a plane ticket without interference by anyone else. But if one has a positive right to cross the ocean, then other actors are going to be involved in the realisation of this right. Any positive right implies that other individuals would be deprived of their negative right to be free from unwanted interference and initiation of force against them (others have a negative obligation not to initiate force). Every positive right imposes an obligation to do something.

Rothbard would perhaps say that one of the examples of negative rights are communication rights (or the right of free speech, which, although not the same, in this case can be used as synonyms). Communication rights can be understood as the right to engage freely in communication without unwanted interference. But Rothbard makes a very important point by formulating the idea that human rights (including free speech) mean that people are only free to use their resources for expressing their ideas, and their freedom to do so will depend on the availability of these resources. This, however, does not mean that some third party is obligated to provide the resources to those who want to exercise free speech. To put it simply, communication rights are determined by, and are limited by, property rights.

\section{COMMUNICATION FREEDOM AND PROPERTY RIGHTS}

This idea is crucial for understanding of the relationship between communication and property. Property rights play a determining role in regards to communication freedom. Rothbard gives the following famous explanation of his idea that human rights, when not put in terms of property rights, turn out to be vague and contradictory:

Take, for example, the "human right" of free speech. Freedom of speech is supposed to mean the right of everyone to say whatever he likes. But the neglected question is: Where? Where does a man have this right? He certainly does not have it on property on which he is trespassing. In short, he has this right only either on his own property or on the property of someone who has agreed, as a gift or in a rental contract, to allow him on the premises. In fact, then, there is no such thing as a separate "right to free speech"; there is only a man's property right: the right to do as he wills with his own or to make voluntary agreements with other property owners (Rothbard, 1977: 238-239).

Communication freedom, or freedom of speech, is not a separate right - it is an extension, or a feature, of property rights. As Stephan Kinsella notes, 
we have a right to do anything at all with and on our own property, provided only that we do not invade others' property borders. We must not lose sight of this crucial libertarian point. If I own a 100 -acres of land, I can prance around naked on it, not because the land is imbued with some "right-to-prance-naked", but because I own the land and it does not (necessarily) violate the property rights of others for me to use my property in this fashion (Kinsella, 2001: 21).

Rothbard develops his idea by explaining that there is no extra "right of free speech" or free press beyond the property rights that a person may have in any given case:

In short, a person does not have a "right to freedom of speech"; what he does have is the right to hire a hall and address the people who enter the premises. He does not have a "right to freedom of the press"; what he does have is the right to write or publish a pamphlet, and to sell that pamphlet to those who are willing to buy it (or to give it away to those who are willing to accept it). Thus, what he has in each of these cases is property rights, including the right of free contract and transfer, which form a part of such rights of ownership (Rothbard, 1998: 113-114).

Rothbard recasts the conflict of property rights $v s$ the freedom of speech by offering a clear solution which prioritises property as the functional and logically consistent solution: the person who writes a letter to the newspaper is not the owner of the newspaper and thus has no right to newspaper space. The act of writing a letter to the paper is an act of requesting, not claiming a right; and the owner can choose to grant the space or to refuse it as a legitimate exercise of the property right in the newspaper space:

only when the "right to free speech" is treated simply as a subdivision of property right does it become valid, workable, and absolute (Rothbard, 1998: 116-117).

These examples epitomise libertarian concept which identifies individual liberties with private property rights, where liberty stems from and is the extension of the right to exclude from property, enjoy one's property as one sees fit, the right to enter contracts and the right to abandon property. This approach to understanding individual (or human) rights as property rights emphasises a very important idea: that private property is not merely an important element of individual's liberty, but it is also a necessary condition for the liberty to be realised and exercised in a practical sense. Private property, its acquisition, ownership, and disposition, is thus the pivot of the freedom of speech.

An individual may have an abstract right of free speech, but to exercise this right this person must stay somewhere or use some medium. If one has not own a yard to speak in, one can not claim the right to use someone else's property to speak while using the right of free speech as the justification for violating property rights. The owner of the property has the exclusionary prerogatives, and even is the owner grants permission to access the property he can limit this access for certain purposes, and ban access for any other purposes. The emphasis on private 
property rights greatly helps to understand multiple related questions related to free speech, focusing on property owner exclusionary prerogatives.

The US legal debate of the 1980s over the right of citizens to use shopping malls as venues for speech activism serves as a good illustration. Can activists enter shopping malls and claim that these are public spaces, thus their use as platform for free speech is justified? From a libertarian perspective, clearly not. As Schoepflin demonstrated,

\begin{abstract}
Shopping centers are private businesses. The public is invited for the limited purpose of doing business with the merchants and not to engage in expressive activities. Speech activists may view shopping centers as ideal forums for the exercise of expressive rights, but the attractiveness of shopping centers does not justify infringing owners' (property) rights. The most basic common law property right is the right to exclusive possession. Property owners are generally free to choose who may use their property, when, and for what purposes. Persons who have been invited onto private property become trespassers if they refuse to leave when requested to do so. Persons who have been invited onto private property become trespassers if they refuse to leave when requested to do so. Persons with permission to be on land become trespassers when their activities exceed the scope of the invitation (Schoepflin, 1989: 145).
\end{abstract}

This logic helps to clarify the long-lasting confusion which stems from the concept of "conflicting rights" which should be "balanced". According to this "balancing" concept (or better say, misconception) free speech and property are distinct, and yet equally important rights, which both need to be protected because we, as a society, recognise their value and acknowledge the need of protecting them (e.g., Arendt, 1958; Habermas, 1987; Garton-Ash, 2016).

But this view would also imply that the need to "balance" different rights requires limiting some rights in order to let other rights stand, and thus, for example, property rights might be limited in some cases should it be necessary for the right of free speech to be protected - this is exactly the logic of those who would argue that speech activists should be allowed to use shopping malls as a speech venues. The conflict can also be seen in the opposite perspective, when one would argue that free speech should be limited if it poses threats to property rights (for instance, when defamation negatively affects the value of owned resources).

This understanding of the existing conflict between rights is popular enough for people to think that it is organic and inevitable, and that a complex system of rules, checks and balances is required to maintain this fragile balance between conflicting rights. Nothing can be further from the truth - to secure SDG target 16.10 of public access to information and protecting fundamental freedoms, property rights need to be prioritised above all else.

\title{
PROPERTY RIGHTS AND SOCIAL MEDIA CENSORSHIP
}

The logic outlined above allows to view from a different angle the controversy which surrounds social media content practice of moderating and taking down 
users posts or banning users altogether. These "censorship" policies of Facebook, Twitter, Instagram or Tumblr received a lot of criticism from the news media and the users for constituting a potential threat to the freedom of expression. With social media becoming the default platform for information seeking, receiving, and imparting, the concerns are understandable, particularly given that the legal and social circumstances are changing rapidly. In the result big social media platforms have to deal with multiple challenges regarding the content which users post, and the ways with deal with these challenges have also changed.

For example, in the past Facebook had positioned itself as a platform, not a publisher. Taking responsibility for what users posted, or acting to censor it, was considered expensive, complicated and unnecessary. Many Facebook executives worried that any such efforts would backfire, so they tried to stay away from content moderating.

Facebook executives soon discovered that Russian hackers were probing Facebook accounts for people connected to the presidential campaigns; they also found Facebook accounts linked to Russian hackers who were messaging journalists to share information from the stolen emails. Following the publicity surrounding these incidents, Facebook had to deal with negative media coverage, pressure from the users, as well as legislators' attention. The latter resulted in Zuckerberg's testifying to the Senate about the platform's role in the 2016 election.

After the incident Facebook started to address the issue of "unwanted" speech and now the company executives say they are working diligently to rid the platform of dangerous posts and to enforce community standards on the platform in order to balance freedom of expression with safety (Fisher, 2018). The company introduced moderators (currently the company uses services of over 15000 of human moderators) to enforce constantly changing standards that are codified in an over 1400 pages instructions manual. The closely held rules are extensive, and they make the company a far more powerful arbiter of global speech than has been publicly recognized or acknowledged by the company itself, as The New York Times has found (Fisher, 2018):

\footnotetext{
The result has too often been arbitrary content deletions and user bans, fueling accusations of political bias: for example, Facebook bans non-violent expressions of "white nationalism", in the US the most notable were permanent bans of a number of rightwing activists and conspiracy theorists and provocateurs, including Milo Yiannopoulos. At the same time Facebook still allows Hizb-ut-Tahrir, banned in Germany, despite its leaders' advocacy of a global caliphate that would substitute Islamic law for secular democracy.
}

Facebook, however, is not the only company which moderates users' content. Censorship regimes are embedded in Twitter's rules on "hateful conduct". They emphasize the protection of "women, people of color, lesbian, gay, bisexual, transgender, queer, intersex, asexual individuals, marginalized and historically underrepresented communities". Specific examples of hate speech include "deadnaming" and the misgendering of trans people. 
Facebook, as well as Twitter and other social media platforms, are often criticised for both inconsistency and inefficiency of implementation of their policies. The Facebook employees who set the guidelines are mostly young engineers and lawyers, try to distill highly complex issues into simple yes-or-no rules. Then the company outsources much of the actual post-by-post moderation to companies that enlist largely unskilled workers, many hired out of call centers. Those moderators, at times relying on Google Translate, have mere seconds to recall countless rules and apply them to the hundreds of posts that dash across their screens each day.

But one should not forget that these are private platforms, and their owners have the right to control their resource. The great aspect of these platforms being private is that the worst they can do is ban the user. Users are not entitled to the services that social media offer -Facebook, Twitter, Instagram or YouTube are privately owned resources with which users interact voluntarily, but which their owners have the right to exclusively control. Even if users do not like their policies, they are free to give negative feedback, but social media companies are free to ignore this feedback. Just because users may enjoy these platforms does not mean that they have a right to have access to them, or force them operate in a particular way. Users are not entitled to have access to Facebook -Facebook offers platforms resources to enjoy on certain conditions and can withdraw the invitation if these conditions are violated. All these decisions are the prerogative of the resource owners.

Thus it would be wrong to say that social media are engaged in "censorship" -they merely exercise their property rights. Laws that govern free speech -like the First Amendment in the US- constrain governments, and not private citizens or companies. There is a difference between a private platform refusing to carry someone ideas on their property and a government prohibiting from speaking on a legitimately owned property with the threat of punishment.

\section{PRIVATE CONTENT MODERATING 'VERSUS’ GOVERNMENT CENSORSHIP}

The important thing about Facebook adopting restrictive community standards is that its own initiative, and not a universally applied government standard that governs all major platforms and even has extraterritorial reach. A private company's initiative, no matter how controversial, is a private matter which still rests on the foundation of voluntary cooperation.

Facebook, Twitter, Tumblr and the like are private companies and that their social media platforms are privately owned resources. No one, including governments, has the right to force property owners to exercise their property rights in any particular way as long as property owners do not violate property rights of others. And by deleting the content or by refusing some individuals access to their resources, social media do not violate anyone's rights, just like any private establishment which refuses a customer does not violate this customer's rights. 
Platform owners have property rights over their businesses and can set the terms of use according to what they see as the most beneficial. Although the general public is prompted to think of Facebook or Twitter as public spaces, they, of course, are not. As much as people have accustomed to having social media, they do not have a right to use them or dictate how they should work. These companies offer their resources to the users on a contractual basis.

Like Twitter and YouTube, Facebook is a private company that users interact with on a wholly voluntary basis - which should mean "to mutual benefit". Users who do not like the platforms's policies are always free to stop using the services. They can also criticise the platform and give public or private feedback if they disagree with the companies' decisions. But they have no right to enforce their preferences on the platform owners, and the owner has all the rights to ignore users' preferences, requests or feedback (albeit facing the potentially negative consequences of shrinking user base). People who do not like Facebook can leave, migrate to another platform (Telegram?), start their own social media on their own terms, or withdraw from online social media altogether. Facebook can not prevent users from doing any of these, as well as from campaigning publicly against Facebook policies. Facebook can delete users' posts, block their accounts or ban them permanently, but can not stop people from using other platforms or punish them by any means apart from legitimately exercising property rights. Facebook can not prosecute, impose fines or imprison users. Governments, on the other hand, can do all these things - prosecute, fine and imprison. While the only mode of interaction in business is voluntary cooperation, the only mode of interaction that the government uses is the use of force or a threat of thereof.

Interestingly enough, while arguing for the necessity of government regulation in social media, Zuckerberg in an interview with ABC News made a claim it should not simply be up to Facebook and other private companies to set and enforce their own rules for participants, especially when it came to political speech. Instead, he claimed that Facebook and other services are now "the digital equivalent of the town square", which invites government regulation and censorship of speech (Zuckerberg remarked that "[companies] have too much power over speech ... that we shouldn't make so many important decisions about speech on our own"). Creating the analogies between social media and town squares Zuckerberg argued that governments should regulate companies just like they do public spaces.

However, until now in the US the courts have ruled that social media platforms are more like shopping malls. In this case, the conservative video producer Prager University, argued that YouTube and other services were effectively public spaces that should have to abide by broader First Amendment guarantees. Which is exactly how Zuckerberg is now characterizing Facebook —as a "town square" (Zuckerberg, 2019). The ruling was that YouTube (and, by extension, other social media services) are private businesses. That is, they are private spaces do not have to allow for freedom of speech the same way that an actual town square does. Such services are free to decide what sort of content appears on its platforms, delete the content or ban certain type of speech: 
In 2018 YouTube (owned by Google, which is in turn part of Alphabet) won a lawsuit brought by Prager $U$ that charged the site was minimizing the reach of conservative points of view, if not outright censoring them. The crux of that case turned on whether YouTube should be treated as the equivalent of a government-licensed broadcast radio or television network and thus have to provide equal distribution to all participants. The ruling was unequivocal that YouTube (and, by extension, other social media services) are private businesses (Gillespie, 2018).

The danger of corporate censorship is of course the fact that the decisions can be arbitrary, unfair and generally go against one's moral or legal intuition. People have solid reasons to be sceptical about Facebook (or any other social media platform) content policy and interference with users' freedoms to post and share what they like. But nonetheless, these are corporate decisions, and no matter how disappointing, they are legitimate exercises of social media owners' property rights, and these decisions are limited in their effect to the scope of the respective platforms. These decisions do not limit the freedom of expression of users, since users are always free to express themselves elsewhere, and just as no one is entitled to having Facebook, Facebook is not obliged to continue to provide its services to anyone on any conditions. The introduction of universal government issued regulations, however, is a totally different story altogether. Apart from limiting the competition and de facto cementing the monopoly of the market leaders, it will effectively limit the free speech and create real censorship with the mechanisms of legal enforcement and prosecution:

What's more, a system of government oversight wouldn't work, anyway: The entire issue with speech policies is that having anyone decide for you what speech is acceptable is a dangerous idea. Asking a government to do this rather than Facebook is trading a bad idea for a truly Orwellian idea. Such a move would be a far more serious threat to free speech than anything we've seen (Fisher, 2018).

\section{COMMUNICATION FREEDOM AS FREE CHOICE}

Corporate content policies are generally vastly preferable over government censorship for another reason: they leave a place for variety with each platform developing its own rules and guidelines. This is particularly important for online media and social media, with different platforms having their distinctive features and intended functionality. Various media satisfy different demands — just like in print, Wall Street Journal has different features from Penthouse. The same is true for social media. They serve different purposes and thus have different strategies, including content policies. A platform design for business networking does not have a role in the market of controversial opinions, while a platform for sharing nude pics has no role in the market of business networking. Some platforms were not intended for sharing controversial opinions and their owners or managers may find certain topics irrelevant or disruptive for the platform's purpose. In this case it is the right of the platform legitimate owner to steer the conversation. 
Luckily, it does not mean that those controversial opinions will be suppressed just because they will no longer be allowed on a particular platform -for example, Facebook. There are other platforms that provide space for different opinions, not matter how controversial they may be. Different purposes that different media can be based on different premises — from commitment to free speech to affiliations with particular political, social or aesthetic values:

By advocating for repercussions from social media platforms which practice censorship, we are merely treating the symptom of a much more fundamental problem, (i.e., government intervention). Rather, we should be advocating for the splintering of all governmental partnerships with firms such as Facebook, among others. It is these economic interventions which fundamentally stymie voluntary freedom of association, and replace it with a militant, state enforced censorship.

Those who are truly against censorship will let the market gradually filter it out. One has to support the property rights, and consequently, free speech of his political enemies in order to uphold that of his. Thus we must advocate for a system in which the state doesn't take sides, nor try to fix the consequences of interventionism through further intervention (Sulker, 2019).

Social media users are capable of finding platforms that represent their preferences and where they can communicate with other people with similar interests. Market mechanisms allow for enough diversity and freedom of choice and association both in physical world as well as online, while state intervention can only push some ideas and opinions outside of the public discourse and effectively crippling free speech.

People have different goals and varied subjective preferences, and they use different means (including online platforms) to replace the feeling of dissatisfaction with a more desirable state of satisfaction. All Internet users have different ideas of what they expect from their online experience, and the best one can do is to allow people to control and moderate their social media life (as well as real life) by themselves.

Individuals who can decide what type of content they want to interact with are usually much more satisfied with the experience they have. And people who advocate some kind of censorship rarely argue that they personally have negative experience of interacting with the content they dislike - usually they demonstrate paternalistic intentions to protect others from some kind of harm. In reality avoiding undesirable materials is extremely easy, and any user is perfectly capable of curating their media consumption. Censoring one's own feed is a definitely more attractive alternative to government-imposed legal standards or even corporate policies (although we need to stress again, that corporate policies, although undesirable and generally ineffective, are perfectly legitimate and the right of platforms owners should be fully respected).

But in the best interest of both the platforms and the users the best thing that can be done is developing media skills (media-literacy competences and media-usage skills) to determine the quality of content one deals with, as well as to Bloch the content one prefers to avoid. Social media and wider online 
space provide enough room for any kind of opinion, and enough tools to avoid opinions one prefers to avoid (which would be an illustration of the selective exposure theory in action - tendency to favor information that reinforces their pre-existing views while avoiding contradictory information.

\section{THE OWNER ALWAYS HAVE THE RIGHT TO DECIDE ON THE CONTENT}

The popular argument suggests that media owners are in a position to influence media content, and even if they do not, the very possibility justifies imposed restraints on their ability to exercise property rights. Regardless of the interests that influence the decisions of the owners of the media, the fact that they can influence the editorial policy compromises media integrity. This proposition is often used as a way to justify some legal limitations on the ability of media owners to influence the content (both in news media or social media platforms).

Indeed for those entrepreneurs who invest in media their investment is not only a business, but also a powerful tool to influence and potentially secure the desired political and economic conditions. Media are a field of political and financial battles, and media owners are often accused of using the media for their own interests rather than in the interest of society.

The idea that media must serve society emerged in the 1920s-1930s both in USA and UK. John Dewey, the philosopher and progressive education activist, is often said to have tacitly inspired public broadcasting. Dewey believed news media ought to play an educational role in public life, publishing and broadcasting information that would lead to greater democratic participation and a stronger sense of community in society. The importance of a news story, he said, "cannot be determined unless the new is placed in relation to the old, to what has happened and been integrated into the course of events" (Dewey, 1981: 347). Following Dewey, progressivists believed that since media are so powerful, people should not allow the profit motive to determine its content, they say capitalist system as a barrier to democratic media. This view was particularly popular among left intellectuals, who trusted neither the motives of media owners nor the tastes of mass audiences. They concluded that media must be used for positive ends, and this is not just a possibility —it is a necessity and an obligation.

The main question that arises when we examine this proposition is based on the very nature of the accusation. Why should media owners act in the interests of anyone apart from their own interests and the interests of their audiences (which, as economics teaches, are aligned by the power of the invisible hand of the market). And why should media owners be more concerned with the interests of society to an extent greater than their interests dictate?

This idea is probably lined to a general misconception that a media owner has some obligations towards society, and must serve society and generally owes to society. We will leave for now the whole discussion if such thing as "the interests of society" even exist (not everyone shares this idea, as Margaret Thatcher famously said, "there's no such thing as society. There are individual men and 
women and there are families"). What is important is that such approach of prioritising social interests over property rights directly violates the very idea of liberty.

If owners have to manage the property nor according to their own preferences and own best knowledge but according to what others tell them to do, they can no longer be consider the real owners. To have property rights means to have the exclusive right to control a particular resource according to its nature. If others dictate how a resource is to be used, they get the right to control it. Any attempt to legally limit the rights of media owners is an attempt to make one person (the owner) a slave to others (those who will dictate how to use the property).

Media owners have the right to influence the editorial policy of their media, dictate the content and control it precisely because they own the media. Of course, owners may for some reason not to use this prerogative and voluntarily withdraw from managing their media. In fact, this happens quite often, and in most such cases the owners are driven by purely utilitarian motives - they may think that their editors, journalists and reporters are more professional and their judgement can help the enterprise prosper. Or that social media platform users know better how to interact with the content.

In any case, free market and competition have effective mechanists of dealing with the problem of content policy formation - those media which are used as means to their owners ends while ignoring the interests of the audience can not be competitive in the long run- people turn away from sources which do not meet their requirements or do not satisfy their needs. If a news media serves the interests of the owner and not the audience people will stop reading it. Only if a media outlet does what the audiences want has it a chance to survive in a competitive market.

In other words, only the content policy that meets the demands of the audience would be a sensible marketing choice. Those media that actively lobby the owners' interests are not likely to become popular. On the other hand, those media who demonstrate their objectivity and serve the audiences well become successful enterprises.

\section{CONCLUSION}

Freedom of expression does not imply that anyone is granted a platform to speak anytime, anywhere and for whatever one may want to say. Freedom of expression only means that one may use one's own resources as a platform to exercise speech, or may seek a platform to do so, as long as others are willing to grant access to their platforms on voluntary basis. Freedom of expression, however, implies that the government can not interfere neither with how individuals use their own resources to speak freely, nor with their voluntary interactions and exchanges regarding the use of legitimately owned resources. Freedom of expression does not require property owners to accommodate those who want to speak on their property, and no one should be given the rights to force them to do so. Demanding social media platforms to ditch their content policies and 
66 force them to refrain from deleting the content they do not want to host would imply coercing property owners to do something they do not want to do, a prohibition of the free use of their property. Social media platforms are driven by user demand and their understanding of it. If someone is silenced on a private company's platform, it means that the content produced by this person is not what this platform owners believe their users will like. And this poses no danger to the freedom of expression as long as there are no laws regulating platform owners; property rights.

Pavel Slutskiy (pavel.slutsky@gmail.com) is a full-time lecturer in Communication Management at the Faculty of Communication Arts, Chulalongkorn University, Bangkok. Born in St. Petersburg, Russia, he continued his education in UK, and then in Russia, where he received PhD in Political Science from St. Peters- burg State University (School of Journalism and Mass Communication). He has published three monographs, three university textbooks and multiple articles on these topics. He also has 15 years of experience as an industry practitioner, entrepreneur, PR-consultant, journalist, editor and a TV-host.

\section{References}

Arendt, Hannah (1958). The Human Condition. Chicago: University of Chicago Press.

Berlin, Isaiah (1958). "Two Concepts of Liberty". In: Isaiah Berlin (1969). Four Essays on Liberty. Oxford: Oxford University Press.

Casero-Ripollés, Andreu (2018). "Research on Political Information and Social Media: Key Points and Challenges for the Future". El Profesional de la Información, 27 (5), pp. 964-974.

Dewey, John (1981). The Later Works, 1925-1953. Carbondale: Southern Illinois University Press.

Fisher, Max (2018). "Inside Facebook's Secret Rulebook for Global Political Speech". The New York Times (December 2018). Available at: <https://www.nytimes.com/2018/12/27/ world/facebook-moderators.html>. Accessed 12 May 2020.

Garton-Ash, Timothy (2016). Free Speech: Ten Principles for a Connected World. Harvard; London: Yale University Press.
Gillespie, Nick (2018). "How Should Facebook (and Twitter, and YouTube, and...) Decide What Speech To Allow?". The Reason. Available at: <https://reason.com/2018/12/31/ how-should-facebook-and-twitter-andyout/>. Accessed 12 May 2020.

Habermas, Jürgen (1987). The Theory of Communicative Action. Vol. 2: Lifeworld and System, T. McCarthy (trans.). Boston: Beacon.

Hansen, Isabella and Lim, Darren J. (2019). "Doxing Democracy: Influencing Elections Via Cyber Voter Interference". Contemporary Politics, 25 (2), pp. 150-171.

Kinsella, Stephan N. (2001). "Against Intellectual Property". Journal of Libertarian Studies, 15 (2), pp. 1-53.

Locke, John (1690/1975). An Essay Concerning Human Understanding. Peter Nidditch (ed.). Oxford: Oxford University Press.

Mazúr, Ján and Patakyová, Mária T. (2019). "Regulatory Approaches to Facebook 
and Other Social Media Platforms: Towards Platforms Design Accountability". Masaryk University Journal of Law and Technology, 13 (2), pp. 219-242.

Rothbard, Murray N. (1977). Power and Market, 2nd ed. Kansas City: Sheed Andrews and McMeel.

—. (1998). The Ethics of Liberty. New York: New York University Press.

Schoepflin, Frederick W. (1989). "Speech Activists in Shopping Centers: Must Property Rights Give Way to Free Expression". Washington Law Review, 64(1), pp. 133-154.
Sulker, Atilla (2019). "What Do We Do 67 About Social Media?". Mises.org. Available at: $<$ https://mises.org/power-market/what-dowe-do-about-social-media>. Accessed 12 May 2020.

Zuckerberg, Mark (2019). "The Internet Needs New Rules. Let's Start in These Four Areas". The Washington Post. Available at: <https:// www.washingtonpost.com/opinions/markzuckerberg-the-internet-needs-new-rules-letsstart-in-these-four-areas/2019/03/29/9e6f050 4-521a-11e9-a3f7-78b7525a8d5f_story.html> . Accessed 12 May 2020. 